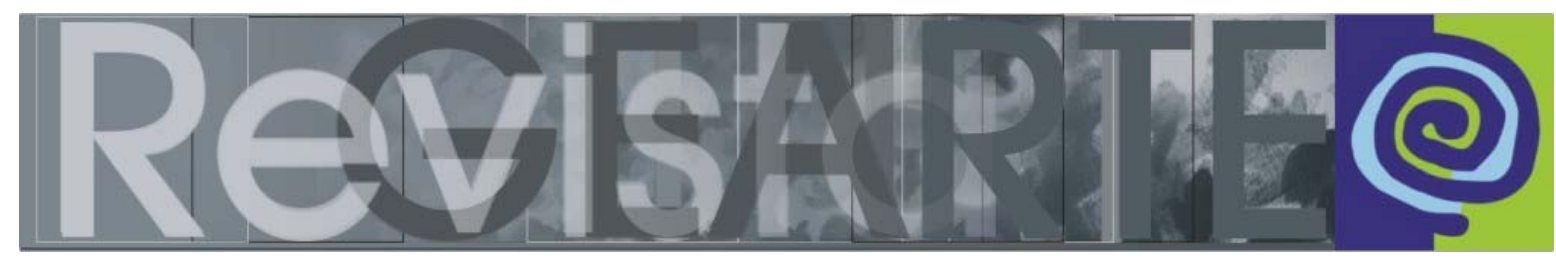

Volume 1, Número 2, Agosto/2014, ISSN 2357-9854

\title{
Artes Visuais e Interdisciplinaridade
}

Pensar numa publicação que pudesse relacionar as artes visuais interdisciplinarmente com outros campos do saber requer uma desconstrução de nossos modos de pensar sobre a produção do conhecimento na Academia. Esse é o mundo das disciplinas. É onde, sob a influência do Positivismo, ainda predomina a organização do conhecimento em disciplinas mais ou menos autônomas.

A crítica a esse paradigma se dá num contexto de emergência de novos conceitos, tais como multidisciplinaridade, interdisciplinaridade e transdisciplinaridade. Esses conceitos podem ser compreendidos como modos de conceber a construção do conhecimento, sendo que cada um configura um tipo de relação/colaboração possível entre disciplinas. Não se trata de destruir o conceito de disciplina, mas de ampliar e apoiar o crescimento de disciplinas envolvidas num processo da produção de conhecimento. A rigor não existe novidade nessa maneira de pensar o conhecimento de modo relacional, pois desde os sofistas gregos já se falava de um desenvolvimento humano como totalidade.

A partir do conceito de complexidade, Morin (2001, p. 41) defende uma reforma do pensamento disciplinar: "a hiperespecialização impede tanto a percepção do global (que ela fragmenta em parcelas), quanto do essencial (que ela dissolve)". Valorizar o paradigma da complexidade implica em reconhecer a insuficiência do modelo disciplinar - redutor do real - e buscar relações. Pensar interdisciplinarmente pode ser um caminho profícuo, "uma forma de compreender e modificar o mundo", como diz Ivani Fazenda (1979). Assim, de diferentes modos, os trabalhos deste número da Revista GEARTE relacionam campos do saber: educação estética e perspectiva desenvolvimental (Freeman); arte, ciência e tecnologia (Richter); museu, patrimônio e cidade (Nunes); pesquisa, ensino de arte e poética (Zordan); artes plásticas e literatura/ilustração infanto-juvenil (Mastroberti); educação estética, infância e formação de professores (Pontes); fotografia e poesia (Vares). 
Norman Freeman, eminente pesquisador sobre produção e compreensão de arte por crianças e jovens, propõe reflexões sobre fatores envolvidos na interpretação de obras de arte e imagens. O artigo "When should we put a name to a picture?" traz contribuições importantes à arte-educação - especificamente em relação à leitura estética - num momento de revisão do paradigma modernista e sua ênfase na percepção dos aspectos formais da obra. Hoje busca-se privilegiar as abordagens interpretativas, deslocando a primazia da abordagem perceptiva. O texto comenta resultados de investigação empírica que mostra que, na interpretação de sentidos durante a leitura estética, as crianças interligam suas conjecturas sobre as intenções do produtor e as palavras ou nomes atribuídos à obra.

Em "Projeto Água: uma proposta interdisciplinar", Ivone Richter nos brinda com seu conhecimento de especialista na temática da interdisciplinaridade, apresentando um projeto realizado através de um convênio internacional que envolveu a Universidade Federal de Santa Maria e a Universidade de Kiel, da Alemanha, na década de noventa. Descreve atividades desenvolvidas por crianças e adolescentes com o objetivo de promover a integração entre educação estética, científica e ambiental, tendo como tema central a água, enfocando seis campos do conhecimento humano: intuitivo, estético, científico, abstrato, tecnológico e ecológico. As reflexões geradas pelo projeto mantêm-se muito atuais, posto que a interdisciplinaridade é um tema privilegiado nas discussões sobre a educação contemporânea.

Lilian do Amaral Nunes nos apresenta o "Museu Efêmero: O Museu é o Mundo. Narrativas artísticas contemporâneas e patrimônio. Mobilização de relações entre pessoas, cidades e bens culturais", em que propõe pensar o mundo como um museu, articulador de passado e futuro, memória e experimentação. Descreve projetos como o "RUA: Realidade Urbana Aumentada. Cartografias Inventadas", que, na contramão dos processos de gentrificação dos espaços urbanos, busca formas inovadoras de experimentação e reinvenção de relações entre pessoas, cidades e memórias, conectando cidades em rede no Brasil, Espanha, Portugal e Colômbia.

No artigo "Por Poéticas no Ensino da Arte: uma sintomatologia" Paola Zordan apresenta, num primeiro momento, três grandes agrupamentos discursivos e os sintomas do ensino de arte no século XX para, posteriormente, passar ao campo de discursos e textos presentes no ensino das artes nas primeiras décadas do século 
XXI, apontando diferentes modos e acepções de trazer a poética para práticas educacionais. Dentre eles, cita o sintoma do poético na escrita de si, no jogo de palavras, na invenção de métodos e nos modos de se conceber o ensino (enSIGNo).

Em "Arte na educação da infância: saberes e práticas da dimensão estética" Gilvânia Maurício Dias de Pontes apresenta sua pesquisa de doutorado na qual investigou a relação entre experiências estéticas e prática docente com linguagens artísticas narradas em memoriais produzidos por professores da educação da infância no curso de Especialização em Ensino de Arte e Educação Física na Infância, desenvolvido pela Universidade Federal do Rio Grande do Norte - UFRN. Além de o aporte teórico ser interdisciplinar, abrangendo diferentes campos de conhecimento como Filosofia, Semiótica, Ensino da Arte e Pedagogia, a metodologia também buscou interfaces entre a Semiótica Discursiva e a Pesquisa (auto)biográfica.

No artigo "O livro como objeto predisposto à interdisciplinaridade", Paula Mastroberti nos convida a pensar o livro simultaneamente como janela, abertura ao conhecimento, seja ele poético ou informativo e como borboleta, forma em si lúdica e poética a solicitar a atenção de crianças e adultos, alfabetizados ou não. A partir da reflexão sobre o livro como objeto estético e comunicativo, objeto cultural e objeto tecnológico, defende uma mediação interdisciplinar do livro ilustrado e da escrita como arte liberta do ensino técnico da língua.

O ensaio visual "Arqueologias íntimas: apontamentos" de Jacqueline de Azevedo Vares articula suas fotografias com fragmentos de poemas de autoria de seu avô, o poeta modernista gaúcho Olmiro de Azevedo (1895-1974), publicados na primeira metade do século XX pela Editora Globo de Porto Alegre/RS. Fotografias mostram os cadernos de manuscritos do poeta, num concerto que harmoniza versos e elementos da natureza. De maneira metafórica, a poesia é animada pela fotografia. Diferentes sistemas semióticos - o texto fotográfico e o literário - se articulam na busca do encantamento que a função poética possibilita.

João Paulo Queiroz (Portugal) nos oferece um rico depoimento em áudio trazendo reflexões sobre o papel da arte-educação na sociedade contemporânea. Defende que, nesse mundo globalizado e complexo, com a hibridação de contextos 
de toda a ordem, deve-se ter especial atenção à arte-educação como campo interdisciplinar que pode promover o desenvolvimento pessoal e a cidadania.

Como diz Morin, "o recorte em disciplinas impossibilita apreender 'o que está tecido junto, ou seja, segundo o sentido original do termo, o complexo" (2001, p. 39). Mas costumamos separar o que foi tecido junto e usamos expressões para nominar nosso pensamento disciplinar, tais como: o mundo das artes, o mundo da cultura, o mundo da ciência, o mundo acadêmico... Talvez a interdisciplinaridade propicie um caminho para não separamos mais as coisas que se entrelaçam na realidade.

\section{Referências}

FAZENDA, Ivani Catarina. Integração e interdisciplinaridade no ensino brasileiro: efetividade ou ideologia? São Paulo: Edições Loyola, 1979.

MORIN, Edgar. Os sete saberes necessários à educação do futuro. São Paulo: Cortez; Brasília: UNESCO, 2001.

Maria Helena Wagner Rossi, Rejane Ledur e Ruth Lerm (Organizadoras) 